\title{
Genetic Analysis of 29 Kindreds with Generalized and Pituitary Resistance to Thyroid Hormone

\author{
Identification of Thirteen Novel Mutations in the Thyroid Hormone Receptor $\beta$ Gene
}

Maria Adams, * Clare Matthews, * Trevor N. Collingwood, * Yukiko Tone, * Paolo Beck-Peccoz, ${ }^{\ddagger}$ and Krishna K. Chatterjee*

${ }^{*}$ Department of Medicine, University of Cambridge, Addenbrooke’s Hospital, Cambridge CB2 2QQ, United Kingdom; and ${ }^{\ddagger}$ Institute of Endocrine Sciences, University of Milan, Ospedale Maggiore, IRCCS, I-20122 Milan, Italy

\begin{abstract}
Resistance to thyroid hormone (RTH), with elevated serum free thyroid hormones and nonsuppressed thyrotropin levels, is either relatively asymptomatic, suggesting a generalized disorder (GRTH) or associated with thyrotoxic features, indicating possible selective pituitary resistance (PRTH). 20 GRTH and 9 PRTH cases, sporadic or dominantly inherited, were analyzed. Affected individuals were heterozygous for single nucleotide substitutions in the thyroid hormone receptor $\beta$ gene, except for a single case of a seven nucleotide insertion. With one exception, the corresponding 13 novel and 7 known codon changes localized to and extended the boundaries of two mutation clusters in the hormone-binding domain of the receptor. 15 kindreds shared 6 different mutations, and haplotype analyses of the mutant allele showed that they occurred independently. The majority (14 out of 19) of the recurrent but a minority (1 out of 10) of unique mutations were transitions of CpG dinucleotides. Mutant receptor binding to ligand was moderately or severely impaired and did not correlate with the magnitude of thyroid dysfunction. There was no association between clinical features and the nature or location of a receptor mutation. These observations suggest that GRTH and PRTH are phenotypic variants of the same genetic disorder, whose clinical expression may be modulated by other non-mutation-related factors. (J. Clin. Invest. 1994. 94:506-515.) Key words: generalized resistance to thyroid hormone • pituitary resistance • thyroid hormone • thyrotropin - thyroid hormone receptors
\end{abstract}

\section{Introduction}

The syndromes of resistance to thyroid hormone (RTH) ${ }^{1}$ are rare disorders characterized by reduced tissue responsiveness

M. Adams and C. Matthews contributed equally to this work.

Address correspondence to Krishna Chatterjee, Department of Medicine, University of Cambridge, Level 5, Addenbrooke's Hospital, Hills Road, Cambridge CB2 2QQ, United Kingdom.

Received for publication 22 December 1993.

1. Abbreviations used in this paper: $\mathrm{FT}_{3}$, free triiodothyronine; $\mathrm{FT}_{4}$, free thyroxine; GRTH, generalized resistance to thyroid hormone; hTR $\beta$, thyroid hormone receptor $\beta ; K_{\mathrm{a}}$, affinity constant; PRTH, pituitary resistance to thyroid hormone; RTH, resistance to thyroid hormone; TRE, thyroid response element; TSH, thyroid stimulating hormone.

J. Clin. Invest.

(C) The American Society for Clinical Investigation, Inc.

$0021-9738 / 94 / 08 / 0506 / 10 \quad \$ 2.00$

Volume 94, August 1994, 506-515 to thyroid hormones (thyroxine $\left[\mathrm{T}_{4}\right]$ and triiodothyronine $\left[\mathrm{T}_{3}\right]$ ). The synthesis of these hormones is controlled by thyroid stimulating hormone (TSH) from the pituitary, and, in turn, they regulate TSH production as part of a negative feedback loop (1). The hallmark of RTH is resistance to thyroid hormone action within the pituitary-thyroid axis, such that continued TSH production drives hypersecretion of $\mathrm{T}_{3}$ and $\mathrm{T}_{4}$ to establish a new equilibrium with high serum levels of free thyroid hormones together with a nonsuppressed TSH. Although this disorder exhibits marked phenotypic variability, two major forms have been described on the basis of clinical features. Many affected individuals are asymptomatic and clinically euthyroid, with characteristic abnormal thyroid function tests, leading to a diagnosis of generalized RTH (GRTH) (2). In other cases, similar hormonal abnormalities are associated with a variety of thyrotoxic features, suggesting that peripheral tissues are less refractory to thyroid hormones than the pituitary, allowing a diagnosis of pituitary resistance (PRTH) to be made (3). In addition, features such as growth retardation in children or hypercholesterolemia indicate that some tissue responses to thyroid hormone can be in the "hypothyroid" range (2).

In humans, two homologous thyroid hormone receptors (hTR $\alpha$ and hTR $\beta$ ) are encoded by separate genes on chromosomes 17 and 3, respectively. Alternative splicing of each gene generates three major receptor isoforms $\mathrm{hTR} \alpha 1, \mathrm{hTR} \beta 1$, and hTR $\beta 2$ with differential tissue expression. Thus hTR $\alpha 1$ and hTR $\beta 1$ are ubiquitously expressed, whereas $\operatorname{TR} \beta 2$, which has been isolated in the rat and mouse, is most highly expressed in the pituitary and hypothalamus (4). Current models suggest that thyroid hormone action is mediated by interaction of these receptors with specific DNA sequences or thyroid response elements (TREs) in the promoter region of target genes. For many target genes, the receptor binds as a heterodimer with the retinoid X receptor (RXR) (5), but homodimeric interactions have also been demonstrated in some cases (6). The presence of ligand results in activation or repression of target gene transcription.

In 1988 , familial GRTH was shown to be tightly linked to the TR $\beta$ gene locus (7). Since then, 26 different hTR $\beta$ gene mutations have been described in a large number of kindreds with this disorder (8-24). More recently, analyses of two unrelated cases of PRTH showed that they also harbored mutations in $\operatorname{hTR} \beta(25,26)$. An early report suggested that the mutations clustered within two regions in the hormone-binding domain of the receptor (11), and a subsequent series has confirmed this observation (22). Consistent with their location, functional studies indicate that the mutant receptors exhibit moderately or markedly impaired ligand-binding properties (27-29). In addition, they are able to inhibit the action of wild-type receptor when coexpressed $(27,28)$. This dominant negative inhibitory activity varies depending on the nature of the mutation (29), as well as the configuration of $\operatorname{TRE}(30,31)$. Evidence in favor 
of the dominant negative effect of mutant receptors in vivo is provided by the observation that individuals who are heterozygous for a complete deletion of one $\operatorname{hTR} \beta$ allele are normal (12), whereas an individual who was homozygous for a dominant negative receptor mutation showed severe resistance (32).

In this study we have analyzed 29 families with RTH from centers throughout Europe, comprising 20 cases with GRTH and 9 with PRTH. In both disorders, affected individuals are heterozygous for mutations in the hTR $\beta$ gene, consistent with a dominant mode of inheritance. In five cases the mutations are sporadic and have presumably arisen de novo. Among 13 novel mutations, one is located in the hinge region of the hormonebinding domain, outside the two previously defined clusters. Haplotype studies suggest that identical mutations have occurred independently in different kindreds. This large series extends previous findings regarding the distribution, possible mechanism, and functional consequences of $\operatorname{TR} \beta$ receptor mutations in RTH.

\section{Methods}

Hormone assays. In a single case (T.B.) serum free $\mathrm{T}_{4}\left(\mathrm{FT}_{4}\right)$ was measured by an SPAC $\mathrm{FT}_{4}$-fraction assay (Byk-Sangtec Diagnostica, Dietzenbach, The Netherlands). All other hormone measurements in Table II were carried out with the same assay methodology. Serum $\mathrm{FT}_{4}$ and free $\mathrm{T}_{3}\left(\mathrm{FT}_{3}\right)$ levels were measured with fluoroimmunometric assays using Delfia technology (Wallac, Milton Keynes, UK). TSH measurements used a sensitive "second generation" assay method (Delfia; Wallac). The intra- and interassay coefficients of variation were $<10 \%$ throughout.

DNA extraction and sequence analysis. Blood samples were obtained from members of each kindred, and leukocyte DNA was extracted using standard techniques. For each index case, exons 4-10 of the hTR $\beta$ gene were amplified using PCR with flanking intronic oligonucleotide primers. Primer sequences are shown in Table I. In each case the antisense primer was 5'-biotinylated to allow single-stranded DNA template to be generated before sequencing. PCR was performed using $1 \mu \mathrm{g}$ of genomic DNA and $10 \mathrm{pmol}$ of each primer in a 50- $\mu \mathrm{l}$ reaction volume containing $10 \mathrm{mM}$ Tris- $\mathrm{HCl}(\mathrm{pH} 8.3), 50 \mathrm{mM} \mathrm{KCl}, 2 \mathrm{mM} \mathrm{MgCl}$, $0.01 \%$ gelatin, $500 \mu \mathrm{M} \mathrm{dNTPs}$, and $0.5 \mathrm{U}$ of Taq polymerase (PerkinElmer Cetus, Norwalk, CT). The reaction conditions were denaturation at $94^{\circ} \mathrm{C}$ for $3 \mathrm{~min}$, then annealing at $55^{\circ} \mathrm{C}$ for $30 \mathrm{~s}$, followed by 30 cycles of extension at $72^{\circ} \mathrm{C}(30 \mathrm{~s})$, denaturation at $94^{\circ} \mathrm{C}(30 \mathrm{~s})$, and annealing at $60^{\circ} \mathrm{C}(30 \mathrm{~s})$. The PCR product was captured using streptavidin-coated magnetic beads (DYNABEADS M-280 streptavidin; DYNAL, Wirral, UK) and then was denatured with $0.2 \mathrm{M} \mathrm{NaOH}$ to remove the nonbiotinylated sense strand. The immobilized biotinylated antisense strand was then sequenced directly using an internal intronic primer (Table I). Two sequencing methods were used: either the dideoxynucleotide method using Sequenase v. 2.0 (USB, Cambridge, UK) or "automated" sequencing using dye-labeled dideoxynucleotide terminators, Sequenase v. 2.0, and an automated DNA sequencer (model 373A; Applied Biosystems, Warrington, UK). Sequencing reactions were performed according to the manufacturer's protocol; excess dye terminators were removed by washing the magnetically immobilized DYNABEADS twice with $0.1 \%$ Tween 20 in $250 \mathrm{mM}$ Tris- $\mathrm{HCl}(\mathrm{pH} 8.0)$ then twice with TE (10 mM Tris, pH 8.0,1 mM EDTA). The beads were resuspended in $4 \mu \mathrm{l}$ of $5: 1(\mathrm{vol} / \mathrm{vol})$ deionized formamide: $50 \mathrm{mM}$ EDTA ( $\mathrm{pH} \mathrm{8.0)}$. After denaturation at $65^{\circ} \mathrm{C}$ for $10 \mathrm{~min}$, the supernatant was loaded on a $6 \%$ acrylamide gel. Each mutation was verified by at least two independent PCR and sequencing reactions.

Haplotyping. Where the same mutation was identified in more than one kindred, genetic unrelatedness was established by haplotype analyses. RFLPs, based on the presence or absence of five separate restriction sites (MspI, DraI, EcoRI, BamHI, and HindIII) in the 5'-noncoding region of the TR $\beta 1$ gene, were used to haplotype the mutant TR $\beta$ gene allele in each kindred. The region encompassing each polymorphic site
Table I. Primers to Amplify and Sequence Exons of hTR $\beta 1$

\begin{tabular}{|c|c|c|}
\hline Exon & Primer & Nucleotide sequence \\
\hline \multirow[t]{3}{*}{4} & Sense & $\begin{array}{l}5^{\prime} \text { AGT GAA TTC TTG AGA AAC AAC } \\
\text { TTG CCT TCC }\end{array}$ \\
\hline & Antisense & $\begin{array}{l}\text { Bio-5' GAT CTG CAG CTT GTT GAA ACA } \\
\text { CCT GAT AAT }\end{array}$ \\
\hline & Seq & 5' GCA TCT CAG CAA AAT CTT GAC \\
\hline \multirow[t]{3}{*}{5} & Sense & $\begin{array}{l}5^{\prime} \text { AGT GAA TTC AAG CCA ATT TTG } \\
\text { TCT CTG GCC }\end{array}$ \\
\hline & Antisense & $\begin{array}{l}\text { Bio-5' GAT CTG CAG TTG TGG ACC CAG } \\
\text { GGC AA }\end{array}$ \\
\hline & Seq & 5' GCT ATA GTG TCT CTT TGA CG \\
\hline \multirow[t]{3}{*}{6} & Sense & $\begin{array}{l}5^{\prime} \text { AGT GAA TTC CGA TTC ATC TCA } \\
\text { TAG TTA TAT GG }\end{array}$ \\
\hline & Antisense & $\begin{array}{l}\text { Bio-5' GAT CTG CAG GAA CCA AAC TGT } \\
\text { TTC CTA ATC }\end{array}$ \\
\hline & Seq & 5' CCA GAA TCA CTG ATT TCA AG \\
\hline \multirow[t]{3}{*}{7} & Sense & $\begin{array}{l}\text { 5' AGT GAA TTC CAG TGG TCC CAC } \\
\text { TCC TGA GGC }\end{array}$ \\
\hline & Antisense & $\begin{array}{l}\text { Bio-5' GAT TCT AGA AAT TGA GGT AGA } \\
\text { AAA CAC TGG }\end{array}$ \\
\hline & Seq & 5' CAG CTT GCT GTG TAT CTT GGG \\
\hline \multirow[t]{3}{*}{8} & Sense & $\begin{array}{l}\text { 5' AGT GAA TTC GTT CAG AAG ATG } \\
\text { ATT TTC TGC }\end{array}$ \\
\hline & Antisense & $\begin{array}{l}\text { Bio-5' GAT CTG CAG ACC CAG TAT TCC } \\
\text { TGG AAA CTG }\end{array}$ \\
\hline & Seq & $5^{\prime}$ AAG CTC CCT TCA ACT TCT TC \\
\hline \multirow[t]{3}{*}{9} & Sense & $\begin{array}{l}5^{\prime} \text { AGT GAA TTC ACA GAA GGT TAT } \\
\text { TCC TAT TGC }\end{array}$ \\
\hline & Antisense & $\begin{array}{l}\text { Bio-5' GAT CTG CAG GCT CTT TGG ATG } \\
\text { CCC ACT AAC }\end{array}$ \\
\hline & Seq & 5' GTT CCT GAC TGG CAT TTT TG \\
\hline \multirow[t]{3}{*}{10} & Sense & $\begin{array}{l}\text { 5' AGT CTG CAG AGG CCT GGA ATT } \\
\text { GGA CAA AGC }\end{array}$ \\
\hline & Antisense & $\begin{array}{l}\text { Bio-5' GGA ATT ATG AGA ATG AAT TCA } \\
\text { GTC AGT }\end{array}$ \\
\hline & Seq & 5' CCC TTC CAT CTC TGA ATC \\
\hline
\end{tabular}

Seq, Sequenase.

was amplified from genomic DNA using PCR and digested with the appropriate enzyme, and the product was analyzed by agarose gel electrophoresis. All PCR primers and reaction conditions were as originally described (33).

$T_{3}$ binding assays. Mutations were recreated by site-directed mutagenesis of the hTR $\beta 1$ cDNA in M13mp18 as described previously (15) and confirmed by sequencing of individual phage plaques. Mutant receptor $\mathrm{cDNAs}$ were subcloned into pGEM $7 \mathrm{z}$ to generate receptor protein by coupled in vitro transcription and translation with rabbit reticulocyte lysate (TNT; Promega, Southampton, UK). The $T_{3}$ binding affinity of each mutant receptor was determined using a filter binding assay. In vitro translated receptor $(2-4 \mu \mathrm{l})$ was incubated for $1 \mathrm{~h}$ at $30^{\circ} \mathrm{C}$ in 500 $\mu$ l binding buffer ( $20 \mathrm{mM}$ Tris- $\mathrm{HCl}, 50 \mathrm{mM} \mathrm{KCl}, 1 \mathrm{mM} \mathrm{MgCl} 2,1 \mathrm{mM}$ dithiothreitol, pH 8.0) containing $0.01 \mathrm{nM}^{125} \mathrm{I}_{-} \mathrm{T}_{3}$ (sp act $3,000 \mu \mathrm{Ci} /$ $\mu \mathrm{g}$ ) and unlabeled competitor ligand. Bound ligand was separated from free by filtering through Millipore HAWP02500 filters (Millipore Corp., Bedford, MA). Scatchard analysis was performed to generate affinity constants $\left(K_{\mathrm{a}}\right)$, and the results shown are the mean of three or more separate determinations. In some cases, specific $T_{3}$ binding was detectable but was too low to be quantified by Scatchard analysis; in these, $K_{\mathrm{a}}$ is indicated as $<0.02 \times 10^{10} \mathrm{M}^{-1}$. BND indicates cases where no specific $\mathrm{T}_{3}$ binding was detected (Table II).

\section{Results}

Hormone levels and clinical features. The results of thyroid function tests of our index cases, when off all drug therapy, are 
Table II. Hormone Data and Genetic Analysis of Kindreds

\begin{tabular}{|c|c|c|c|c|c|c|c|c|c|c|c|c|}
\hline Kindred* & $\begin{array}{l}\text { Sex of } \\
\text { index } \\
\text { case }\end{array}$ & $\begin{array}{c}\text { Age of } \\
\text { index case } \\
\text { at } \\
\text { presentation }\end{array}$ & $\begin{array}{c}\mathbf{F T}_{4} \\
(9.0-20 \\
\text { pmol/liter })\end{array}$ & $\begin{array}{c}\mathbf{F T}_{3} \\
(3.0-7.5 \\
\text { pmol/liter) }\end{array}$ & $\begin{array}{c}\text { TSH } \\
(0.4-4.0 \\
\text { mU/liter })\end{array}$ & Phenotype & Inheritance ${ }^{\ddagger}$ & $\begin{array}{l}\text { Nucleotide } \\
\text { change }\end{array}$ & Exon & $\begin{array}{c}\text { Codon } \\
\text { change }\end{array}$ & $\begin{array}{c}K_{\mathrm{a}}^{\| \prime} / 10^{10} \mathrm{M}^{-1} \\
(\mathrm{SEM}) \\
\mathrm{WT}=2.2 \\
(0.2)\end{array}$ & $\begin{array}{l}\text { Members } \\
\text { analyzed" }\end{array}$ \\
\hline & & $y r$ & & & & & & & & & & \\
\hline G. P. & $\mathbf{M}$ & 23 & 29 & 15 & 2.5 & GRTH & $\mathrm{Sp}$ & 1076 GTT to GAT & 8 & V264D & $<0.02$ & $1 \mathrm{~A}, 4 \mathrm{U}$ \\
\hline deG. & $\mathbf{F}$ & 22 & & $\begin{array}{l}\text { See Table } \\
\text { III }\end{array}$ & & GRTH & $\mathrm{F}$ & $1232 \mathrm{CGC}$ to CAC & 9 & R316H & $<0.02$ & $3 \mathrm{~A}, 1 \mathrm{U}$ \\
\hline C. $\mathbf{M}$. & F & 22 & 53 & 16 & 1.5 & GRTH & $\mathbf{F}$ & $1234 \mathrm{GCT}$ to ACT & 9 & A317T & $0.28(0.05)$ & $2 \mathrm{~A}, 1 \mathrm{U}$ \\
\hline P. C. & $\mathrm{F}$ & 12 & 23 & 16 & 2.3 & GRTH & $\mathrm{Sp}$ & $1234 \mathrm{GCT}$ to ACT & 9 & $\mathrm{~A} 317 \mathrm{~T}$ & $0.28(0.05)$ & $2 A, 6 U$ \\
\hline P. M. & $\mathbf{F}$ & 11 & 29 & 9 & 2.0 & GRTH & $\mathbf{F}$ & 1244 CGC to CAC & 9 & R320H & $0.83(0.12)$ & $3 \mathrm{~A}, 4 \mathrm{U}$ \\
\hline S. C. & $\mathbf{F}$ & 31 & 34 & 14 & 4.2 & GRTH & $\mathbf{F}$ & 1244 CGC to CTC & 9 & R320L & $0.21(0.06)$ & $5 \mathrm{~A}, 1 \mathrm{U}$ \\
\hline G. M. & $\mathbf{M}$ & 37 & 40 & 11 & 3.6 & PRTH & $\mathbf{F}$ & 1244 CGC to CTC & 9 & R320L & $0.21(0.06)$ & $2 \mathrm{~A}, 1 \mathrm{U}$ \\
\hline S. T. & F & 13 & 49 & 14 & 2.1 & PRTH & F & 1247 TAT to TGT & 9 & Y321C & $0.04(0.02)$ & $2 \mathrm{~A}, 5 \mathrm{U}$ \\
\hline B. B. & $\mathbf{M}$ & 25 & 46 & 18 & 6.9 & GRTH & $\mathbf{F}$ & 1280 GGG to GAG & 9 & G332E & $0.04(0.01)$ & $2 \mathrm{~A}, 3 \mathrm{U}$ \\
\hline J. M. & $\mathbf{M}$ & 14 & 71 & 13 & 4.1 & PRTH & $\mathbf{F}$ & 1297 CGG to TGG & 9 & R338W & $0.21(0.06)$ & $2 \mathrm{~A}, 2 \mathrm{U}$ \\
\hline R. $M$. & $\mathbf{F}$ & 28 & 16 & 6 & 185 & PRTH & $\mathrm{Sp}$ & 1297 CGG to TGG & 9 & R338W & $0.21(0.06)$ & $1 \mathrm{~A}, 4 \mathrm{U}$ \\
\hline L. M. & $\mathbf{F}$ & 31 & 36 & 8 & 1.4 & GRTH & F & 1297 CGG to TGG & 9 & R338W & $0.21(0.06)$ & $3 \mathrm{~A}, 5 \mathrm{U}$ \\
\hline N. M. & $\mathrm{F}$ & 9 & 28 & 13 & 2.4 & PRTH & $\mathrm{F}$ & 1298 CGG to CTG & 9 & R338L & $0.57(0.13)$ & $2 \mathrm{~A}, 2 \mathrm{U}$ \\
\hline B. $\mathrm{K}$. & $\mathbf{M}$ & 16 & 64 & 16 & 4.1 & GRTH & NK & 1316 GGG to GAG & 9 & G344E & BND & $1 \mathrm{~A}, 3 \mathrm{U}$ \\
\hline S. S. & $\mathbf{F}$ & 41 & 44 & 14 & 2.5 & PRTH & NK & 1330 CTG to ATG & 9 & V349M & $0.51(0.04)$ & $1 \mathrm{~A}, 3 \mathrm{U}$ \\
\hline M. S. & $\mathrm{F}$ & 41 & 27 & 15 & 1.1 & PRTH & NK & 1571 CGG to CAG & 10 & R429Q & $0.46(0.11)$ & $1 \mathrm{~A}, 1 \mathrm{U}$ \\
\hline M. A. & $\mathbf{M}$ & 34 & 31 & 12 & 7.8 & GRTH & $\mathbf{F}$ & 1571 CGG to CAG & 10 & R429Q & $0.46(0.11)$ & $2 \mathrm{~A}$ \\
\hline L. O. & $\mathbf{F}$ & 2 & 25 & 9 & 1.4 & PRTH & Sp & 1577 ATA to ACA & 10 & I431T & $0.02(0.01)$ & $1 \mathrm{~A}, 4 \mathrm{U}$ \\
\hline C. Ma. & $\mathbf{M}$ & 37 & 25 & 12 & 5.6 & GRTH & F & 1597 CGC to TGC & 10 & R438C & $0.67(0.15)$ & $2 \mathrm{~A}, 1 \mathrm{U}$ \\
\hline B. W. & $\mathbf{M}$ & 42 & 36 & 12 & 2.7 & GRTH & $\mathbf{F}$ & $1598 \mathrm{CGC}$ to $\mathrm{CAC}$ & 10 & R438H & $0.51(0.20)$ & $5 \mathrm{~A}, 3 \mathrm{U}$ \\
\hline C. $S$. & $\mathbf{M}$ & 55 & 39 & 11 & 5.8 & GRTH & NK & $1598 \mathrm{CGC}$ to CAC & 10 & R438H & $0.51(0.20)$ & $1 \mathrm{~A}$ \\
\hline G. $S$. & $\mathrm{F}$ & 54 & 46 & 17 & 1.5 & GRTH & NK & $1598 \mathrm{CGC}$ to CAC & 10 & R438H & $0.51(0.20)$ & $1 \mathrm{~A}, 2 \mathrm{U}$ \\
\hline J. H. & $\mathbf{M}$ & 35 & 35 & 13 & 1.5 & GRTH & $\mathbf{F}$ & $1598 \mathrm{CGC}$ to $\mathrm{CAC}$ & 10 & R438H & $0.51(0.20)$ & $5 \mathrm{~A}$ \\
\hline S. N. & $\mathrm{F}$ & 17 & 69 & 17 & 2.2 & GRTH & $\mathbf{F}$ & ACTCTTC 1638i & 10 & fs 452 & BND & $3 \mathrm{~A}, 1 \mathrm{U}$ \\
\hline S. H. & $\mathbf{F}$ & 25 & 35 & 13 & 3.3 & GRTH & $\mathrm{Sp}$ & $1642 \mathrm{CCT}$ to ACT & 10 & P453T & $0.44(0.08)$ & $1 \mathrm{~A}, 2 \mathrm{U}$ \\
\hline P. A. & $\mathbf{F}$ & 28 & 44 & 10 & 2.0 & GRTH & F & $1642 \mathrm{CCT}$ to ACT & 10 & P453T & $0.44(0.08)$ & $2 \mathrm{~A}, 1 \mathrm{U}$ \\
\hline M. C. & $\mathrm{F}$ & 22 & 35 & 12 & 1.5 & GRTH & $\mathbf{F}$ & $1642 \mathrm{CCT}$ to TCT & 10 & P453S & $0.79(0.19)$ & $3 \mathrm{~A}, 2 \mathrm{U}$ \\
\hline T. B. & $\mathbf{M}$ & 45 & 25 & 22 & 1.9 & PRTH & NK & $1642 \mathrm{CCT}$ to GCT & 10 & P453A & $0.38(0.03)$ & $1 \mathrm{~A}, 5 \mathrm{U}$ \\
\hline$M . P$. & $\mathrm{F}$ & 35 & 9 & 11 & 5.0 & GRTH & $\mathrm{F}$ & $1663 \mathrm{GAG}$ to AAG & 10 & E460K & $0.55(0.14)$ & $2 \mathrm{~A}, 1 \mathrm{U}$ \\
\hline
\end{tabular}

* Index cases with disrupted pituitary-thyroid axis shown in italics. $\mathrm{FT}_{4}$ measurement in TB used a different assay (normal range 9-17 pmol/liter). ${ }^{\ddagger}$ F, familial; Sp, sporadic; NK, not known. ${ }^{\S}$ Codon nomenclature based on a predicted protein sequence of 1-461 residues (59). Novel mutations are shown in bold. " $K_{\mathrm{a}}$, affinity constants for $\mathrm{T}_{3}$ binding by receptors; WT, wild type; BND, binding not detected. ' ${ }^{1} \mathrm{~A}$, mutation with abnormal thyroid function; $U$, no mutation with normal thyroid function.

summarized in Table II, together with their clinical classification. In two cases (R.M., M.P.), the hormone data are confounded by prior treatment which has disrupted the integrity of the pituitary-thyroid axis. The remainder exhibited biochemical abnormalities which are characteristic of RTH in that both serum $\mathrm{FT}_{4}$ (mean 39 pmol/liter, range 23-71 pmol/liter) and $\mathrm{FT}_{3}$ (mean 13 pmol/liter, range 8-18 pmol/liter) concentrations were elevated, with a failure to suppress TSH secretion (mean $3.0 \mathrm{mU} /$ liter, range $1.1-5.6 \mathrm{mU} /$ liter). The majority of these individuals were asymptomatic with few clinical signs other than a goiter and were therefore classified as cases of GRTH. In nine cases, the presence of thyrotoxic symptoms including palpitations, anxiety, tremor, heat intolerance, insomnia, weight loss, and increased stool frequency led to a diagnosis of PRTH. Two individuals (G.M., J.M.) have undergone unsuccessful partial thyroidectomies and several others (N.M., L.O., T.B., S.S.) have been treated with 3,5,3'-triiodothyroacetic acid to alleviate thyrotoxic symptoms. One patient with PRTH
(R.M.) has had surgery and radioiodine therapy to ablate the thyroid. Full details of the clinical features of several patients have been described previously (A.M., 34; B.B., 35; N.M., 36; B.K., 37; T.B., 38).

In two kindreds (deG. and M.P.) we have documented RTH in association with thyroid function tests which are less markedly abnormal. The propositus in kindred deG. presented because of a goiter, but was relatively asymptomatic. Serial thyroid function tests in this patient, as well as members of her family, are shown in Table III. Three individuals (propositus, mother, and sister) showed elevated serum $\mathrm{FT}_{4}$ levels but, interestingly, corresponding $\mathrm{FT}_{3}$ concentrations were elevated to varying levels on some occasions but normal at other times. In the father, serum $\mathrm{FT}_{4}$ and $\mathrm{FT}_{3}$ levels were well within the normal range. In kindred M.P., the index case was initially noted to have an elevated serum total $T_{4}$ concentration (175 nmol/liter, normal 75-145 nmol/liter) and TSH level ( $7.7 \mathrm{mU} /$ liter). The suspicion of a pituitary tumor on CT scan was not 
Table III. Sequential Hormone Values in Kindred deG.

\begin{tabular}{ccccc}
\hline $\begin{array}{c}\text { Subject* } \\
\text { (age) }\end{array}$ & Date & $\begin{array}{c}\mathrm{FT}_{4}{ }^{\ddagger} \\
(9.0-18.0 \\
\mathrm{pmol} / \text { iter })\end{array}$ & $\begin{array}{c}\mathrm{FT}_{3}{ }^{\ddagger} \\
(3.0-8.0 \\
\mathrm{pmol} / \text { iter })\end{array}$ & $\begin{array}{c}\mathrm{TSH}^{\ddagger} \\
(0.24-4.5 \\
\mathrm{pmol} / \text { iter })\end{array}$ \\
\hline $\begin{array}{c}\text { Propositus } \\
(22)\end{array}$ & 1989 & 25.9 & 8.8 & 0.5 \\
& 1992 & 22.4 & 7.1 & 0.8 \\
Mother & 1993 & 27.5 & 9.8 & 0.7 \\
$(48)$ & 1990 & 21.1 & 6.2 & 0.4 \\
& 1992 & 24.6 & 10.3 & 0.4 \\
Sister & 1993 & 21.7 & 7.3 & 0.3 \\
$(24)$ & 1990 & 19.8 & 8.8 & 0.7 \\
& 1992 & 21.0 & 8.1 & 0.7 \\
Father & 1993 & 19.9 & 6.3 & 0.6 \\
$(58)$ & 1990 & 9.9 & 5.6 & 0.5 \\
& 1992 & 9.9 & 3.9 & 0.5 \\
\hline
\end{tabular}

* Subjects with $\mathrm{R} 316 \mathrm{H}$ mutation shown in bold. ${ }^{\ddagger}$ Same assay method as in Table II but note different normal range in this institution.

confirmed at hypophysectomy. She was subsequently maintained on $60 \mu \mathrm{g} / \mathrm{d}$ of $\mathrm{T}_{3}$ replacement with high serum $\mathrm{FT}_{3}$ (11 $\mathrm{pmol} /$ liter) and low $\mathrm{FT}_{4}$ ( 9 pmol/liter) levels, but TSH secretion remained abnormal ( $5.0 \mathrm{mU} /$ liter $)$ (Table II). Her mother was asymptomatic but noted to have a goiter, tremor and resting tachycardia with a serum $\mathrm{FT}_{4}$ concentration ( 19 pmol/liter) at the upper limit of normal, and elevated $\mathrm{FT}_{3}$ ( 7.9 pmol/liter) and nonsuppressed TSH (5.0 mU/liter) levels, whereas her father had normal thyroid function tests $\left(\mathrm{FT}_{4} 14 \mathrm{pmol} / \mathrm{liter}\right.$, $\mathrm{FT}_{3} 6.2 \mathrm{pmol} /$ liter, TSH $1.7 \mathrm{mU} /$ liter).

Genetic studies. On the basis of biochemical abnormalities, an autosomal dominant mode of inheritance was documented in 18 kindreds; 5 cases (G.P., P.C., R.M., L.O., S.H.) were clearly sporadic in that both parents were unaffected. In the remaining six kindreds, the inheritance pattern could not be established because no other affected family members were identified and both parents were not available for analyses. In all 29 cases, affected individuals were found to be heterozygous for a mutation in the TR $\beta$ gene (Table II). 20 different mutations were identified, comprising 13 novel and 7 previously described mutations. 19 are single nucleotide substitutions resulting in a codon change in the predicted protein sequence (Fig. $1 \mathrm{~A}$ ). In one case, a duplication of seven nucleotides causes a shift in reading frame and the addition of four codons at the carboxyl terminus of the receptor, together with alteration of some residues between codons 452 and 461 (Fig. $1 B$ ). With one exception, all these mutations localize to exons 9 and 10 , corresponding to two regions within the hormone-binding domain which have contained the majority of mutations reported to date (2). In a single case (G.P.), a mutation in exon 8 leads to a valine to aspartic acid substitution at codon 264 (V264D) which is located in the hinge region of the receptor.

Having identified a mutation in the index case, all other available first-degree relatives within each kindred were analyzed for this defect by direct sequence analysis. In every family, we found a complete concordance between biochemical evidence of RTH and a receptor gene mutation. Conversely, individuals with normal thyroid function tests did not harbor a receptor gene defect (data not shown). Finally, exons 4-10, encoding the entire $\beta$ receptor apart from the first eight residues, were sequenced in each index case, and no additional mutations were detected.

Haplotype analysis of kindreds with identical mutations. We have documented the occurrence of six different mutations in more than one kindred. To determine whether this was likely to be due to separate mutational events or a shared genetic ancestry, we haplotyped the $\operatorname{TR} \beta$ gene alleles of affected and unaffected individuals in each family using five different RFLPs located at the 5' end of the gene. Examples of such analyses in two families harboring the R320L receptor mutation are shown in Fig. 2. In affected individuals from kindred S.C., the mutant receptor allele exhibits a different pattern of RFLPs (M, d) compared with the allele containing the mutation in kindred G.M. (m, D). These results confirm that the mutation has occurred independently in the two families. Similar studies have established that the R338W mutation in two families (J.M., L.M.) and the $\mathrm{R} 438 \mathrm{H}$ mutation in four families (B.W., C.S., G.S., J.H.) are associated with different allelic backgrounds, confirming genetic unrelatedness. In three other cases (R.M., P.C., S.H.), the receptor mutations are sporadic, indicating that they have arisen de novo. This is associated with either no progeny (S.H., R.M.) or transmission to a single offspring below reproductive age (P.C.), making a relationship with other kindreds harboring the same defect unlikely. The $\mathrm{R} 429 \mathrm{Q}$ receptor mutation was identified in two apparently unrelated kindreds, but we were not able to analyze sufficient family members to confirm this.

Ligand-binding properties of mutant receptors. In comparison to in vitro synthesized wild-type receptor, which bound $\mathrm{T}_{3}$ with an affinity of $2.2 \times 10^{10} \mathrm{M}^{-1}$, the ligand-binding affinities of the mutant receptor proteins were variably impaired (Table II). The majority showed a moderate reduction in $T_{3}$ binding $\left(K_{\mathrm{a}} \mathrm{s}\right.$ ranging from 0.83 to $0.02 \times 10^{10} \mathrm{M}^{-1}$ ); two mutants (V264D, R316H) exhibited detectable but low levels of specific $\mathrm{T}_{3}$ binding with affinities which could not be quantified reliably $\left(<0.02 \times 10^{10} \mathrm{M}^{-1}\right)$, and in two other cases (G344E, fs 452) no specific $\mathrm{T}_{3}$ binding was detected. Although serum free thyroid hormone levels were uniformly elevated, there was no clear correlation between the impairment in ligand-binding affinities of the mutant receptors and $\mathrm{FT}_{4}$ levels as an index of the degree of resistance in the pituitary-thyroid axis. Thus, two highly deleterious mutations were associated with markedly elevated $\mathrm{FT}_{4}$ levels (G344E, $64 \mathrm{pmol} / \mathrm{liter}$; fs $452,58-70$ pmol/liter), whereas three other mutant receptors with comparably reduced affinities for $\mathrm{T}_{3}$ led to only modestly elevated $\mathrm{FT}_{4}$ levels (V264D, 29 pmol/liter; I431T, 25 pmol/liter; R316H, 19-27 pmol/liter). Identical mutations were also associated with highly divergent $\mathrm{FT}_{4}$ concentrations, e.g., R338W in kindreds L.M. and J.M. ( $\mathrm{FT}_{4}$ 30-36 pmol/liter vs 58-71 pmol/liter) or A317T in the P.C. and A.M. kindreds ( $\mathrm{FT}_{4} 23 \mathrm{pmol} /$ liter vs 53-55 pmol/liter).

Correlation of genotype with clinical features. Our observations show that in 20 index cases a receptor mutation was associated with GRTH, whereas in 9 individuals thyrotoxic features suggested PRTH, confirming and extending two recent reports $(25,26)$ that document hTR $\beta 1$ mutations in PRTH. An autosomal dominant mode of inheritance was recorded in both GRTH and PRTH, and sporadic cases occurred with approximately equal frequency in both disorders (G.P., P.C., S.H. with GRTH; R.M., L.O. with PRTH). There was no clear correlation between the clinical phenotype and the nature of the receptor mutation. In three instances, the same mutation was associated with either a GRTH or a PRTH phenotype in different kindreds 


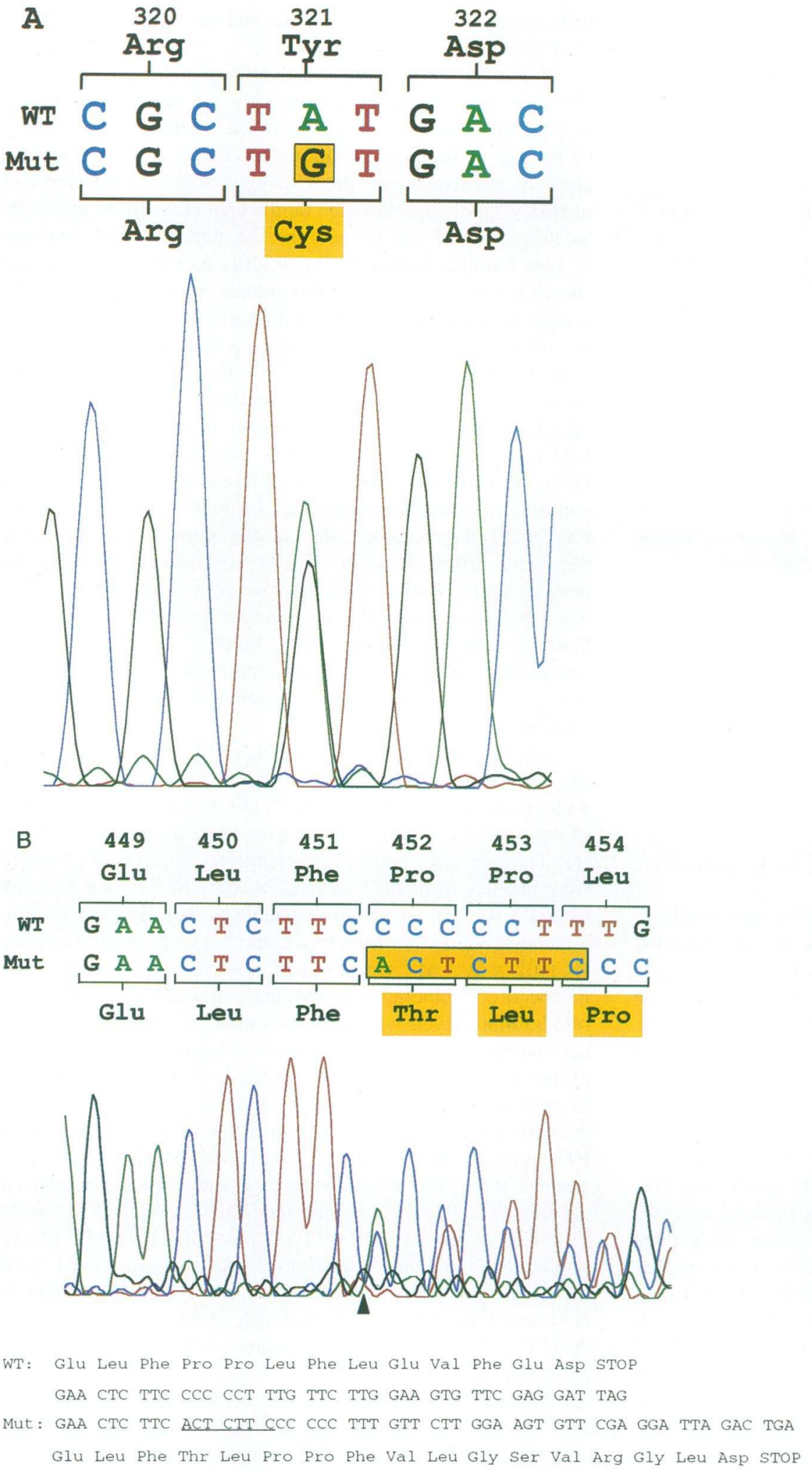

Figure 1. (A) Automated direct sequence analysis of exon 9 of the TR $\beta$ gene in patient S.T., showing a heterozygous $\mathrm{G}$ for $\mathrm{A}$ substitution at nucleotide 1247 (highlighted). This alters codon 321 from tyrosine (Tyr) in the wild type (WT) to cysteine (Cys) in the mutant (Mut) allele. (B) Automated direct sequence analysis of exon 10 of the TR $\beta$ gene in patient S.N. The arrowhead after codon 451 indicates the point of insertion of seven nucleotides in the mutant allele. The nucleotide sequences and corresponding codons of the wild type ( $W T$ ) and mutant $(M u t)$ alleles are shown above. The seven nucleotide insertion, which duplicates the preceding sequence ACTCTTC, is highlighted. This insertion causes a shift in reading frame, which alters some codons between 452 and 461 and eliminates the normal termination codon (462). The nucleotide and predicted amino acid sequences around the insertion (underlined) are shown at the bottom of Fig. $1 B$.

(R338W in L.M. and R.M., R429Q in M.A. and M.S., R320L in S.C. and G.M.). Divergent clinical features were also documented in several members of a single family with the same receptor mutation. This was exemplified by kindreds G.M., S.T., and J.M., where thyrotoxic features led to a diagnosis of PRTH in the index case, but other relatives harboring the same receptor defect remained asymptomatic and clinically euthyroid despite comparably elevated thyroid hormone levels. There was no correlation between the clinical phenotype and location of mutations in the receptor gene. Thus, six cases of PRTH were associated with exon 9 mutations, and the remaining three were associated with mutations in exon 10. 


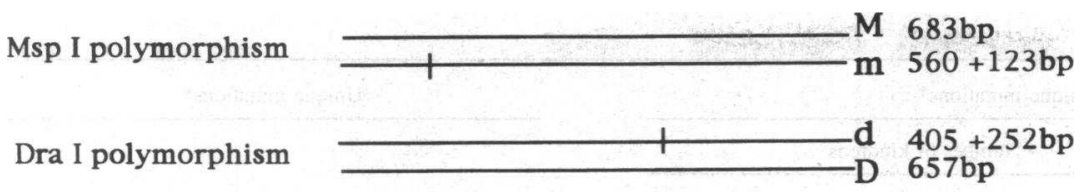

Family G.M.
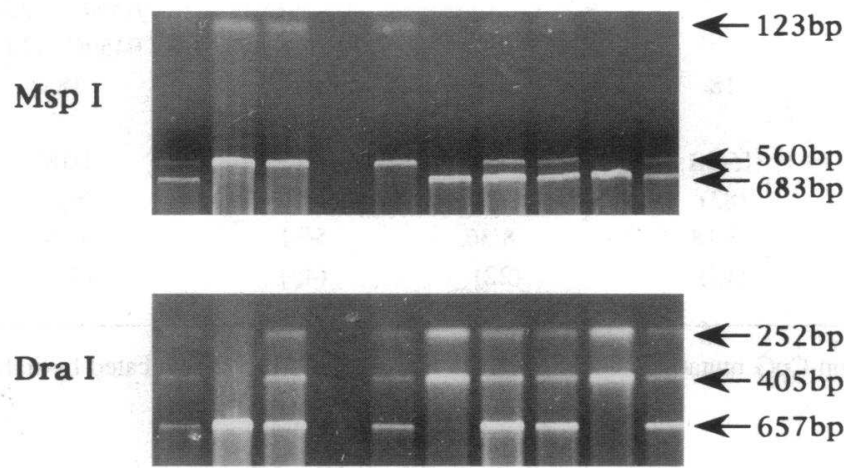

Figure 2. Haplotype analysis of G.M. and S.C. kindreds using MspI and DraI RFLPs. The area surrounding each polymorphic site was amplified by PCR of unaffected (open symbols) and affected (filled symbols) family members. The absence ( $\mathrm{M}$, D) or presence $(\mathrm{m}, \mathrm{d})$ of each restriction endonuclease site was assessed after agarose gel electrophoresis and was used to determine the haplotype of the mutant allele in each kindred. In each family the haplotype associated with the mutation is ringed.

\section{Discussion}

The cardinal feature of resistance to thyroid hormone is an impairment of feedback regulation within the pituitary-thyroid axis, manifested by elevated serum free thyroid hormone concentrations, together with a nonsuppressed TSH level. We have described 29 kindreds exhibiting these biochemical abnormalities and identified 20 different mutations in the $\operatorname{TR} \beta$ gene in affected individuals, occurring sporadically or in a dominantly inherited manner. On this background, the clinical manifestations were widely variable, with the absence or presence of thyrotoxic features leading to a diagnosis of GRTH or PRTH, respectively.

In males with the $\mathrm{X}$-linked androgen insensitivity syndrome, deleterious mutations have been described throughout the androgen receptor (39), while recessively inherited vitamin Dresistant rickets is characterized by DNA-binding domain mutations in the majority of cases $(40,41)$. By contrast, dominantly inherited RTH is associated with receptor mutations which cluster within the hormone-binding domain, and our analyses confirm this observation with the location of 28 mutations conforming to the two "hot spot" regions described previously (11, 22). However, novel mutations within our series expand the boundaries of each hot spot region which now extend from codons 310 to 349 and 429 to 461 . In addition, we have identi- fied a single mutation (V264D) which localizes to the hinge (D) domain of the receptor, outside the two major mutation clusters and representing only the second such example described (16). The ability of the mutant proteins to bind ligand is moderately or severely impaired (Table II). Other studies have shown that mutant receptors retain the ability to bind to DNA (27-29) either as homodimers (42) or heterodimers with the retinoid $X$ receptor (30). These functional properties correlate with the observation that RTH mutations lie outside the DNA-binding domain and highly conserved motifs (43-45) that are known to be involved in dimerization. We and others $(27,28)$ have also shown that the mutant receptor proteins inhibit wild-type receptor action in a dominant negative manner. Importantly, this inhibition has been observed with reporter genes containing not only positive TREs (29-31), but also the human TSH $\alpha$ promoter $(15,28,46)$, which is negatively regulated by hTR $\beta$. A number of models have been proposed to account for dominant negative inhibition $(28,42)$, but recent studies indicate that artificial mutations that abolish DNA binding or heterodimerization with RXR are able to abrogate dominant negative inhibitory effects with reporter genes containing the hTSH $\alpha$ promoter or positive TREs $(47,48)$. These observations suggest that receptor mutations which impair ligand-dependent transcriptional function, yet retain DNA binding and dimerization potential, are associated with RTH. In particular, 


\begin{tabular}{|c|c|c|c|c|c|c|c|}
\hline & \multicolumn{4}{|c|}{ Nonunique mutations* } & \multicolumn{3}{|c|}{ Unique mutations* } \\
\hline & & \multicolumn{3}{|c|}{ Number of kindreds } & \multirow[b]{2}{*}{ This series } & \multirow[b]{2}{*}{ Other } & \multirow[b]{2}{*}{ Total } \\
\hline & & This series & Other & Total & & & \\
\hline & R316H & 1 & $1(23)$ & 2 & V264D & A234T (16) & \\
\hline & A317T & 2 & $3(11,22,24)$ & 5 & Y321C & M310T (22) & \\
\hline & $\mathbf{R 3 2 0 H}$ & 1 & $2(18,24)$ & 3 & $G 332 E$ & D322H (19) & \\
\hline & $R 320 L$ & 2 & 0 & 2 & $R 338 L$ & $G 332 R$ & \\
\hline & R320C & 0 & $2(17,24)$ & 2 & G344E & $\Delta 337 \mathrm{~T}(14)$ & \\
\hline & R338W & 3 & $5(19,24-26)$ & 8 & V349M & $\mathrm{Q} 340 \mathrm{H}$ (13) & \\
\hline & R429Q & 2 & 0 & 2 & I431T & G345R (8) & \\
\hline & R438H & 4 & $2(10,22)$ & 6 & $\mathbf{R 4 3 8 C}$ & G345S (15) & \\
\hline & $P 453 T$ & 2 & $2(11,21)$ & 4 & $f_{s} 452$ & G345V (11) & \\
\hline & $P 453 S$ & 1 & $1(22)$ & 2 & $P 453 A$ & $G 345 D(22)$ & \\
\hline & & & & & E460K & G347E (11) & \\
\hline & & & & & & M442V (11) & \\
\hline & & & & & & K443E (20) & \\
\hline & & & & & & $f_{s} 448 \quad$ (11) & \\
\hline & & & & & & L450H (19) & \\
\hline & & & & & & P453H (9) & \\
\hline & & & & & & $f s 454 \quad(22)$ & \\
\hline & & & & & & F459C (19) & \\
\hline Total & 10 & 18 & 18 & 36 & 11 & 18 & 29 \\
\hline CpG dinucleotide & & $13 / 18$ & $15 / 18$ & $28 / 36$ & $2 / 11$ & $1 / 18$ & $3 / 29$ \\
\hline$(\%)$ & & $(72)$ & (83) & (78) & (18) & (6) & $(10)$ \\
\hline GC-rich region & & $5 / 18$ & $3 / 18$ & $8 / 36$ & $5 / 11$ & $9 / 18$ & $14 / 29$ \\
\hline (\%) & & (28) & (17) & (22) & (45) & $(50)$ & $(48)$ \\
\hline
\end{tabular}

* CpG dinucleotide transitions are shown in bold. Other, non-CpG mutations which occur in GC-rich regions are indicated by italics.

we suggest that the ability to exert a dominant negative effect within the pituitary-thyroid axis is a key property of mutant proteins and generates the characteristic biochemical abnormality that leads to the detection of the disorder. As a corollary, it is tempting to speculate that mutations elsewhere in the receptor that are also transcriptionally impaired elude discovery because they lack dominant negative activity and are therefore biochemically and clinically silent.

However, such structure-function correlations might not be the sole determinants of the clustered distribution of receptor mutations in RTH. Our data also indicate that within these two major clusters, mutations are nonuniformly distributed, such that some codon changes are particularly frequent. Weiss et al. (24) reported that six RTH mutations occurring in more than one kindred were all either transitions in CpG dinucleotides or occurred in GC-rich regions (defined as $\geq 4$ consecutive Gs or Cs). In our series also (Table IV), a disproportionate number of recurrent RTH mutations are CpG transitions (72\%), and the remainder occur in GC-rich regions (28\%). By contrast, only 2 out of 11 unique mutations are CpG transitions. An analysis of all published cases of RTH (Table IV) agrees with these proportions, with $\mathrm{CpG}$ transitions constituting the majority $(83 \%)$ of recurrent and a minority $(6 \%)$ of unique mutations. CpG dinucleotides are frequent sites of point mutation in several other genes (e.g., Factor IX); this probably results from deamination of 5 'methyl-cytosine (thought to occur preferentially in CpG motifs) to thymidine, converting CG to TG or CA (49, 50). We therefore suggest that, where a mutation-prone CpG dinucleotide concurs with a cluster, certain codon changes are overrepresented (e.g., R338W ×10, R438H ×7, A317T ×5).

Although we have observed complete concordance between resistance in the pituitary-thyroid axis and a TR $\beta$ gene defect, individual patients exhibited widely variable serum levels of $\mathrm{FT}_{4}, \mathrm{FT}_{3}$, and $\mathrm{TSH}$, which did not correlate with the nature of the mutation or the ligand-binding properties of mutant receptor proteins. We have shown recently that the biological activity of TSH is variably elevated in patients with RTH (51) and suggest that this might, in part, account for the variations in serum free thyroid hormone levels. Kindred deG. showed mildly elevated thyroid hormone concentrations with temporal variations such that, in some instances, either $\mathrm{FT}_{4}$ or $\mathrm{FT}_{3}$ levels (but never both) were within the normal range. All biochemically affected individuals in this family harbored an arginine to histidine mutation in codon 316 of hTR $\beta$. In a separate kindred, the same mutation was associated with biochemical resistance in one patient but normal thyroid function tests in two other members (23). The authors correlated these observations with the lack of dominant negative activity of this mutant receptor on a positive TRE-containing reporter gene and suggested the possibility of a second genetic defect to account for resistance in their index case.'We have found that the $\mathrm{R} 316 \mathrm{H}$ receptor mutant does exert a dominant negative effect, particularly when tested using the negatively regulated hTSH $\alpha$ gene promoter (data not shown). To reconcile these differences, we suggest that this mutation can engender mild resistance in the pituitary-thyroid axis, but that the severity of this impaired feedback can be 
modulated by other factors. This may account for the association of the R316H mutation with mild RTH in our kindred but normal thyroid function in another family. In this context, a recent study (52), which showed normal but above average $\mathrm{FT}_{4}$ levels in unaffected members of a kindred with RTH, supports the notion that other non-receptor-related processes can influence the biochemical phenotype.

Earlier studies had not described a clear mode of inheritance in PRTH, leading to the suggestion that it might represent a different pathophysiologic entity (2). In our series, nine individuals exhibited a marked preponderance of thyrotoxic signs and symptoms leading to a diagnosis of PRTH. We have recorded a dominant mode of inheritance in four PRTH families with cosegregation of mutations and thyroid dysfunction. Sporadic mutations were recorded with approximately equal frequency in GRTH and PRTH. Both GRTH and PRTH phenotypes were observed in different families harboring the same mutation and could coexist within affected members of a single kindred. Even in a single individual (e.g., N.M.), thyrotoxic symptoms were variable allowing intermittent treatment with thyromimetics. Although we have not found a clear association between particular mutations and PRTH, it is intriguing that the R338W mutation has been associated with PRTH in four out of our five kindreds (Table II and our unpublished data) as well as in further two cases reported in the literature $(25,26)$. Overall, these observations suggest that GRTH and PRTH represent part of the variable clinical spectrum of a single genetic entity. Several factors could account for the variable patterns of tissue resistance to thyroid hormone. First, $\mathrm{T}_{3}$ responsiveness may be modulated by the differing tissue distribution of $\operatorname{TR} \alpha$ and $\operatorname{TR} \beta$ receptor isoforms. Thus, the predominance of TR $\alpha 1$ expression in myocardium (53) and consequent retention of sensitivity to thyroid hormone might account for the frequency of cardiac thyrotoxic symptoms in PRTH as well as the resting tachycardia that has been observed in GRTH $(16 ; 18)$. Conversely, we suggest that the relative predominance of TR $\beta 1$ in liver (54) leads to hepatic resistance manifested by normal serum sex hormone-binding globulin levels in both forms of RTH (55). Second, the relative expression of mutant versus wild-type $\operatorname{TR} \beta$ receptor alleles could regulate the degree of resistance. Support for this concept is provided by Mixson et al. (56) who correlated overexpression of the mutant receptor allele in skin fibroblasts with growth retardation in two children with RTH. However, a separate study demonstrated no differences in mutant and wild-type mRNA expression in other cases $(57,58)$. The dominant negative potency of mutant receptors, which has been shown to differ depending on the nature and configuration of TRE (30, 31 ), is a third variable which may control target gene resistance to $\mathrm{T}_{3}$ action. Other potential sources of phenotypic variation are speculative, but include variable receptor interactions with RXR isoforms, hTR $\alpha 2$, or other accessory (TRAPs) and adaptor proteins.

In a small number of cases, we have been unable to find nucleotide sequence abnormalities in exons 4-10 of the hTR $\beta$ gene, despite biochemical evidence of RTH. Possible explanations in these cases include a somatic $\operatorname{TR} \beta 1$ mutation whose expression is limited so as to be undetectable in peripheral blood leukocyte DNA or a mutation in $\operatorname{TR} \beta 2$, the pituitary-specific receptor isoform. Homologous mutations in hTR $\alpha 1$ are capable of exerting a dominant negative effect in vitro (31), although based on the tissue distribution of $\operatorname{TR} \alpha 1$ one might predict that such mutations would be associated with cardiac or neurological features possibly in the absence of abnormal thyroid function.
Lastly, the possibility of other novel, nonreceptor mechanisms by which TR signaling could be disrupted to produce RTH should be considered.

The occurrence of sporadic hTR $\beta$ mutations in a number of families, as well as identical mutations in unrelated kindreds, suggests that de novo mutations account for a proportion of RTH cases and that the disorder might be more common than appreciated hitherto. The widespread availability of $\mathrm{FT}_{4}$ and sensitive TSH assays allows the biochemical detection of RTH and this can now be combined with screening exons 7-10 in $\operatorname{hTR} \beta$ using the robust, automated direct sequencing techniques we have described to make a definitive diagnosis. In GRTH, early recognition of the disorder is beneficial in preventing inappropriate thyroid ablative treatment, and in PRTH the judicious lowering of thyroid hormone levels may help to alleviate thyrotoxic symptoms. The combined use of hormone assay and genetic technologies will facilitate the screening of neonates or selected groups to determine both the prevalence of this condition and its phenotypic and genetic spectrum.

\section{Acknowledgments}

We thank A. Sakurai and L. J. deGroot for providing genomic sequence information for hTR $\beta$. We are deeply indebted to C. Beardwell, P. de Nayer, A. Hermus, T. Howlett, I. MacFarlane, J. McKiernan, R. Newton, W. Reinhardt, S. Shalet, O. Sundquist, S. Wallis, A. Weetman, and M. White for contributing the families.

This work was supported by the Wellcome Trust and the Medical Research Council (MRC) (UK). C. Matthews is an MRC Training Fellow, and V. K. K. Chatterjee is a Wellcome Senior Clinical Research Fellow. P. Beck-Peccoz was supported by Ministero dell'Universitá e della Ricerca Scientifica e Tecnologia and Consiglio Nazionale delle Ricerche.

\section{References}

1. Chin, W. W. 1991. Nuclear thyroid hormone receptors. In Nuclear Hormone Receptors. M. G. Parker, editor. Academic Press Ltd., London. 79-96.

2. Refetoff, S., R. E. Weiss, and S. J. Usala. 1993. The syndromes of resistance to thyroid hormone. Endocr. Rev. 14:348-399.

3. Gershengorn, M. C., and B. D. Weintraub. 1975. Thyrotropin-induced hyperthyroidism caused by selective pituitary resistance to thyroid hormone. A new syndrome of inappropriate secretion of TSH. J. Clin. Invest. 56:633-642.

4. Lazar, M. A. 1993. Thyroid hormone receptors: multiple forms, multiple possibilities. Endocr. Rev. 14:184-193.

5. Kliewer, S. A., K. Umesono, D. J. Mangelsdorf, and R. M. Evans. 1992. Retinoid X receptor interacts with nuclear hormone receptors in retinoic acid, thyroid hormone and vitamin D3 signalling. Nature (Lond.). 355:446-449.

6. Yen, P. M., D. S. Darling, R. L. Carter, M. Forgione, P. K. Umeda, and W. W. Chin. 1992. Triiodothyronine $\left(\mathrm{T}_{3}\right)$ decreases binding to DNA by $\mathrm{T}_{3^{-}}$ receptor homodimers but not receptor-auxiliary protein heterodimers. J. Biol. Chem. 267:3565-3568.

7. Usala, S. J., A. E. Bale, N. Gesundheit, C. Weinberger, R. W. Lash, F. E. Wondisford, O. W. McBride, and B. D. Weintraub. 1988. Tight linkage between the syndrome of generalized thyroid hormone resistance and the human c-erbA $\beta$ gene. Mol. Endocrinol. 2:1217-1220.

8. Sakurai, A., K. Takeda, K. Ain, P. Ceccarelli, A. Nakai, S. Seino, G. I Bell, S. Refetoff, and L. J. deGroot. 1989. Generalized resistance to thyroid hormone associated with a mutation in the ligand-binding domain of the human thyroid hormone receptor $\beta$. Proc. Natl. Acad. Sci. USA. 86:8977-8981.

9. Usala, S. J., G. E. Tennyson, A. E. Bale, R. W. Lash, N. Gesundheit, F. E. Wondisford, D. Accili, P. Hauser, and B. D. Weintraub. 1990. A base mutation of the c-erbA $\beta$ thyroid hormone receptor in a kindred with generalized thyroid hormone resistance. J. Clin. Invest. 85:93-100.

10. Boothroyd, C. V., B. T. Teh, N. K. Hayward, P. E. Hickman, G. J. Ward, and D. P. Cameron. 1991. Single base mutation in the hormone binding domain of the thyroid hormone receptor $\beta$ gene in generalised hormone resistance demonstrated by single stranded conformation polymorphism analysis. Biochem. Biophys. Res. Commun. 178:606-612.

11. Parrilla, R., A. J. Mixson, J. A. McPherson, J. H. McClaskey, and B. D. 
Weintraub. 1991. Characterization of seven novel mutations of the c-erbA $\beta$ gene in unrelated kindreds with generalized thyroid hormone resistance. Evidence for two "hot spot" regions of the ligand binding domain. J. Clin. Invest. 88:21232130.

12. Takeda, K., S. Balzano, A. Sakurai, L. J. DeGroot, and S. Refetoff. 1991. Screening of nineteen unrelated families with generalized resistance to thyroid hormone for known point mutations in the thyroid hormone receptor $\beta$ gene and the detection of a new mutation. J. Clin. Invest. 87:496-502.

13. Usala, S. J., J. B. Menke, T. L. Watson, J. Berard, W. E. C. Bradley, A. E. Bale, R. W. Lash, and B. D. Weintraub. 1991. A new point mutation in the $3,5,3^{\prime}$-triiodothyronine binding domain of the c-erb $\mathrm{A} \beta$ thyroid hormone receptor is tightly linked to generalised thyroid hormone resistance. J. Clin. Endocrinol. \& Metab. 72:32-38.

14. Usala, S. J., J. B. Menke, T. L. Watson, F. E. Wondisford, B. D. Weintraub, J. Berard, W. E. C. Bradley, S. Ono, O. T. Mueller, and B. B. Bercu. 1991. A homozygous deletion in the c-erbA $\beta$ thyroid hormone receptor gene in a patient with generalised thyroid hormone resistance: isolation and characterization of the mutant receptor. Mol. Endocrinol. 5:327-335.

15. Adams, M., T. Nagaya, Y. Tone, J. L. Jameson, and V. K. K. Chatterjee. 1992. Functional properties of a novel mutant thyroid hormone receptor in a family with generalised thyroid hormone resistance syndrome. Clin. Endocrinol. (Oxf.). 36:281-289.

16. Behr, M., and U. Loos. 1992. A point mutation (Ala 229 to $\mathrm{Thr}$ ) in the hinge domain of the c-erb $\mathrm{A} \beta$ thyroid hormone receptor gene in a family with generalised thyroid hormone resistance. Mol. Endocrinol. 6:1119-1126.

17. Burman, K. D., Y. Y. Djuh, D. Nicholson, P. Rhooms, L. Wartofsky, H. G. Fein, S. J. Usala, E. Hao, W. E. C. Bradley, J. Berard, and R. C. Smallridge. 1992. Generalised thyroid hormone resistance: identification of an arginine to cystine mutation in codon 315 of the c-erb A beta thyroid hormone receptor. $J$. Endocrinol. Invest. 15:573-579.

18. Cugini, C. D., Jr., J. W. Leidy, B. S. Chertow, J. Berard, W. E. C. Bradley, J. B. Menke, E. Hao, and S. J. Usala. 1992. An arginine to histidine mutation in codon 315 of the c-erb $\mathrm{A} \beta$ thyroid hormone receptor in a kindred with generalised resistance to thyroid hormone results in a receptor with significant 3,5,3'-triiodothyronine binding activity. J. Clin. Endocrinol. Metab. 74:1164-1170.

19. Mixson, A. J., R. Parilla, S. C. Ransom, E. A. Wiggs, J. H. McClaskey, P. Hauser, and B. D. Weintraub. 1992. Correlation of language abnormalities with localisation of mutations in the $\beta$ thyroid hormone receptor in 13 kindreds with generalised resistance to thyroid hormone: identification of four new mutations. J. Clin. Endocrinol. \& Metab. 75:1039-1045.

20. Sasaki, S., H. Nakamura, T. Tagami, Y. Miyoshi, K. Tanaka, and H. Imura. 1992. A point mutation of the $T_{3}$ receptor $\beta 1$ gene in a kindred of generalised resistance to thyroid hormone. Mol. Cell. Endocrinol. 84:159-166.

21. Shuto, Y., I. Wakabayashi, N. Amuro, S. Minami, and T. Okazaki. 1992. A point mutation in the $3,5,3^{\prime}$-triiodothyronine binding domain of thyroid hormone receptor $\beta$ associated with a family with generalised resistance to thyroid hormone. J. Clin. Endocrinol. \& Metab. 75:213-217.

22. Takeda, K., R. E. Weiss, and S. Refetoff. 1992. Rapid localisation of mutations in the thyroid hormone receptor $\beta$ gene by denaturing gradient gel electrophoresis in 18 families with thyroid hormone resistance. J. Clin. Endocrinol. \& Metab. 74:712-719.

23. Geffner, M. E., F. Su, N. S. Ross, J. M. Hershman, C. Van Dop, J. B. Menke, E. Hao, R. K. Stanzak, T. Eaton, H. H. Samuels, and S. J. Usala. 1993. An arginine to histidine mutation in codon 311 of the $c-e r b A \beta$ gene results in a mutant thyroid hormone receptor that does not mediate a dominant negative phenotype. J. Clin. Invest. 91:538-546.

24. Weiss, R. E., M. Weinberg, and S. Refetoff. 1993. Identical mutations in unrelated families with generalized resistance to thyroid hormone occur in cytosine-guanine-rich areas of the thyroid hormone receptor beta gene. J. Clin Invest. 91:2408-2415.

25. Mixson, A. J., J. C. Renault, S. Ransom, D. L. Bodenner, and B. D. Weintraub. 1993. Identification of a novel mutation in the gene encoding the $\beta$ triiodothyronine receptor in a patient with apparent selective pituitary resistance to thyroid hormone. Clin. Endocrinol. (Oxf.). 38:227-234.

26. Sasaki, S., H. Nakamura, T. Tagami, Y. Miyoshi, T. Nogimori, T. Mitsuma, and H. Imura. 1993. Pituitary resistance to thyroid hormone associated with a base mutation in the hormone binding domain of the human 3,5,3'-triiodothyronine receptor beta. J. Clin. Endocrinol. \& Metab. 76:1254-1258.

27. Sakurai, A., T. Miyamoto, S. Refetoff, and L. J. DeGroot. 1990. Dominant negative transcriptional regulation by a mutant thyroid hormone receptor- $\beta$ in a family with generalised thyroid hormone resistance. Mol. Endocrinol. 4:19881994.

28. Chatterjee, V. K. K., T. Nagaya, L. D. Madison, S. Datta, A. Rentoumis, and J. L. Jameson. 1991. Thyroid hormone resistance syndrome. Inhibition of normal receptor function by mutant thyroid hormone receptors. J. Clin. Invest. 87:1977-1984.

29. Meier, C. A., B. M. Dickstein, K. Ashizawa, J. H. McClaskey, P. Muchmore, S. C. Ransom, J. B. Menke, E. H. Hao, S. J. Usala, B. B. Bercu, et al. 1992. Variable transcriptional activity and ligand binding of mutant $\beta 13,5,3^{\prime}-$ triiodothyronine receptors from four families with generalised resistance to thyroid hormones. Mol. Endocrinol. 6:248-258.
30. Meier, C. A., C. Parkison, A. Chen, K. Ashizawa, S. C. Meier-Heusler, P. Muchmore, S-y. Cheng, and B. D. Weintraub. 1993. Interaction of human $\beta 1$ thyroid hormone receptor and its mutants with DNA and retinoid $X$ receptor $\beta$. $\mathrm{T}_{3}$ response element-dependent dominant negative potency. J. Clin. Invest. 92:1986-1993.

31. Zavacki, A. M., J. W. Harney, G. A. Brent, and P. R. Larsen. 1993. Dominant negative inhibition by mutant thyroid hormone receptors is thyroid hormone response element and receptor isoform specific. Mol. Endocrinol. 7:1319-1330.

32. Ono, S., I. D. Schwartz, O. T. Mueller, A. W. Root, S. J. Usala, and B. B. Bercu. 1991. Homozygosity for a dominant negative thyroid hormone receptor gene responsible for generalised thyroid hormone resistance. J. Clin. Endocrinol. \& Metab. 73:990-994.

33. Ganly, P. S., N. Jarad, R. M. Rudd, and P. H. Rabbitts. 1992. PCR-based RFLP analysis allows genotyping of the short arm of chromosome 3 in small biopsies from patients with lung cancer. Genomics. 12:221-228.

34. Daubresse, J. C., B. Dozin-Van Roye, P. De Nayer, and M. De Visscher. 1980. Partial resistance to thyroid hormones: reduced affinity of lymphocyte nuclear receptors for T3 in two siblings. In Thyroid Research VIII, Proceedings of the Eighth International Thyroid Congress. J. R. Stockgit and S. Nagataki, editors. Australian Academy of Science, Canberra. 295-298.

35. Williams, G., M. Kraenzlin, L. Sandler, J. Burrin, A. Law, S. Bloom, and G. F. Joplin. 1986. Hyperthyroidism due to non-tumoral inappropriate TSH secretion: effect of long-acting somatostatin analogue (SMS 201-995). Acta. Endocrinol. 113:42-46.

36. Crino, A., P. Borelli, R. Salvatori, D. Cortelazzi, R. Roncoroni, and P. Beck-Peccoz. 1992. Anti-iodothyronine autoantibodies in a girl with hyperthyroidism due to pituitary resistance to thyroid hormones. J. Endocrinol. Invest. 15:113120.

37. Lindstedt, G., P. A. Lundberg, B. Sjogren, I. Ernst, and O. Sundquist. 1982. Thyroid hormone resistance in a 35 y.o. man with recurrent goitre. Scand. J. Clin. Lab. Invest. 42:585-593.

38. Hermus, A., H. Ross, P. Van Liessum, A. Naber, A. Smals, and P. Kloppenborg. 1991. Hyperthyroidism due to inappropriate secretion of TSH: diagnosis and management. Neth. J. Med. 38:193-198.

39. McPhaul, M. J., M. Marcelli, S. Zoppi, J. E. Griffin, and J. D. Wilson. 1993. The spectrum of mutations in the androgen receptor gene that causes androgen resistance. J. Clin. Endocrinol. \& Metab. 76:17-23.

40. Saijo, T., M. Ito, E. Takeda, A. H. M. Mahbubul Huq, E. Naito, I. Yokota, T. Sone, J. W. Pike, and Y. Kuroda. 1991. A unique mutation in the vitamin D receptor gene in three Japanese patients with vitamin D-dependent rickets type II: utility of single-strand conformation polymorphism analysis for heterozygous carrier detection. Am. J. Hum. Genet. 49:668-673.

41. Hughes, M. R., P. J. Malloy, D. G. Kieback, R. A. Kesterson, J. W. Pike, D. Feldman, and B. W. O'Malley. 1988. Point mutations in the human vitamin D receptor gene associated with hypocalcemic rickets. Science (Wash. DC). 242:1702-1705.

42. Yen, P. M., A. Sugawara, S. Refetoff, and W. W. Chin. 1992. New insights on the mechanism(s) of the dominant negative effect of mutant thyroid hormone receptor in generalized resistance to thyroid hormone. J. Clin. Invest. 90:18251831.

43. Forman, B. M., C-r. Yang, M. Au, J. Casanova, J. Ghysdael, and H. H. Samuels. 1989. A domain containing leucine-zipper-like motifs mediate novel in vivo interactions between the thyroid hormone and retinoic acid receptors. Mol. Endocrinol. 3:1610-1626.

44. O'Donnell, A. L., and R. J. Koenig. 1990. Mutational analysis identifies a new functional domain of the thyroid hormone receptor. Mol. Endocrinol. 4:715-720.

45. Spanjaard, R. A., D. S. Darling, and W. W. Chin. 1991. Ligand-binding and heterodimerization activities of a conserved region in the ligand-binding domain of the thyroid hormone receptor. Proc. Natl. Acad. Sci. USA. 88:85878591.

46. Nagaya, T., N. L. Eberhardt, and J. L. Jameson. 1993. Thyroid hormone resistance syndrome: correlation of dominant negative activity and location of mutations. J. Clin. Endocrinol. \& Metab. 77:982-990.

47. Nagaya, T., L. D. Madison, and J. L. Jameson. 1992. Thyroid hormone receptor mutants that cause resistance to thyroid hormone: evidence for receptor competition for DNA sequences in target genes. J. Biol. Chem. 267:1301413019.

48. Nagaya, T., and J. L. Jameson. 1993. Thyroid hormone receptor dimerisation is required for dominant negative inhibition by mutations that cause thyroid hormone resistance. J. Biol. Chem. 268:15766-15771.

49. Cooper, D. N., and H. Yousoufian. 1988. The CpG dinucleotide and human genetic disease. Hum. Genet. 78:151-155.

50. Cooper, D. N., and M. Krawczak. 1990. The mutational spectrum of single base-pair substitutions causing human genetic disease: patterns and predictions. Hum. Genet. 85:55-74.

51. Persani, L., M. Tonacchera, P. Vitti, and P. Beck-Peccoz. 1994. Enhanced biological activity of circulating TSH in patients with thyroid hormone resistance. J. Clin. Endocrinol. \& Metab. 78:1034-1039.

52. Weiss, R. E., C. Marcocci, G. Bruno-Bossio, and S. Refetoff. 1993. Multi- 
ple genetic factors in the heterogeneity of thyroid hormone resistance. J. Clin. Endocrinol. \& Metab. 76:257-259.

53. Falcone, M., T. Miyamato, F. Fierro-Renoy, E. Macchia, and L. J. DeGroot. 1992. Antipeptide polyclonal antibodies specifically recognise each human thyroid hormone receptor isoform. Endocrinology. 131:2419-2429.

54. Rodd, C., H. L. Schwartz, K. A. Strait, and J. H. Oppenheimer. 1991. Ontogeny of hepatic nuclear triiodothyronine receptor isoforms in the rat. Endocrinology. 131:2559-2564.

55. Beck-Peccoz, P., R. Roncoroni, S. Mariotti, G. Medri, C. Marcocci, G. Brabant, F. Forloni, A. Pinchera, and G. Faglia. 1990. Sex hormone binding globulin measurement in patients with inappropriate secretion of thyrotrophin (IST): evidence against selective pituitary hormone resistance in non-neoplastic IST. J. Clin. Endocrinol. \& Metab. 71:19-25.

56. Mixson, A. J., P. Hauser, G. Tennyson, J. C. Renault, D. L. Bodenner, and B. D. Weintraub. 1993. Differential expression of mutant and normal beta
$\mathrm{T}_{3}$ receptor alleles in kindreds with generalized resistance to thyroid hormone. $J$. Clin. Invest. 91:2296-2300.

57. Hayashi, Y., O. E. Janssen, R. E. Weiss, Y. Murata, H. Seo, and S. Refetoff. 1993. The relative expression of mutant and normal thyroid hormone receptor genes in patients with generalised resistance to thyroid hormone determined by estimation of their specific messenger ribonucleic acid products. J. Clin. Endocrinol. \& Metab. 76:64-69.

58. Klann, R. C., B. Torres, J. B. Menke, C. T. Holbrook, B. B. Bercu, and S. J. Usala. 1993. Competitive polymerase chain reaction quantitation of c-er$\mathrm{bA} \beta 1, \mathrm{c}$-erbA $\alpha 1$, and c-erbA $\alpha 2$ messenger ribonucleic acid levels in normal, heterozygous, and homozygous fibroblasts of kindred $\mathrm{S}$ with thyroid hormone resistance. J. Clin. Endocrinol. \& Metab. 77:969-975.

59. Sakurai, A., A. Nakai, and L. J. DeGroot. 1990. Structural analysis of human thyroid hormone receptor $\beta$ gene. Mol. Cell. Endocrinol. 71:8391 . 